The Geneva Papers, 2006, 31, (38-45)

(C) 2006 The International Association for the Study of Insurance Economics 1018-5895/06 $\$ 30.00$

www.palgrave-journals.com/gpp

\title{
Our World
}

\section{Ron Pressman}

GE Insurance Solutions, 9201 State Line Road, Kansas City, MO 64114, U.S.A.

E-mail: jesse.resendiz@ge.com

The insurance industry is a critical foundation of the global economy, a fact that is often overlooked in our haste to deal with the challenges of our competitive markets. Because of the financial security and protection we provide for people, property and reputations, new buildings are built, planes fly, risks are taken and economies around the world grow. Our world is changing, and we must change with it. As insurers, we must recognize the broader, global reality in which our businesses are operating. This paper will address how rating agencies, regulatory scrutiny, underwriting discipline, loss-cost inflation, catastrophes, tort costs, and emerging issues are affecting the industry. Solutions and best practices will be discussed. In addition to facing and eliminating the issues discussed in this paper, we must deliver what customers want: consistency, service, expertise, security, financial strength and integrity. The best way to deliver all of this is through customer service; it's at the centre of GE Insurance Solutions' brand promise.

The Geneva Papers (2006) 31, 38-45. doi:10.1057/palgrave.gpp.2510062

Keywords: ratings; scrutiny; underwriting; loss cost; catastrophes; emerging issues

\section{Introduction}

The insurance industry is a critical foundation of the global economy, a fact that is often overlooked in our haste to deal with the challenges of our competitive markets.

Because of the financial security and protection we provide for people, property and reputations, new buildings are built, planes fly, risks are taken and economies around the world grow. We have a joint responsibility as an industry to support free, fair and competitive markets so we can provide our customers with value and effective risk solutions. We also have an obligation to maintain and strengthen our businesses so they can provide long-term security for our customers.

Our world is changing, and we must change with it. We face new and shifting issues as business leaders and as an industry. Make no mistake, we as insurers must improve our current situation. Although our industry faces a myriad of challenges such as ratings recalibrations, investigations, explosive loss-cost growth and rising catastrophe costs, I believe we can build a promising future by addressing these issues directly and openly. This paper focuses on these issues as well as potential solutions.

\section{Challenges to our global industry}

As insurers, we must recognize the broader, global reality in which our businesses are operating. For example, rating agencies such as A.M. Best, Standard \& Poor's and 
Moody's have been recalibrating the industry during the past 4 years. A.M. Best has downgraded twice as many companies since 2000 as it has upgraded. This recalibration is, in great measure, due to rating agencies' concerns about lagging operating performance.

Adding to that pressure is the newest issue we must face - we are under extraordinary regulatory scrutiny as an industry. We have been an industry under challenge for some time for our inability to deliver consistent returns, now we are facing a credibility crisis on the fundamental issue of integrity. Clearly we must standas an industry - for integrity, transparency and candor. Never has this been more crucial.

We have a shared interest with regulators worldwide in creating stable markets with transparency and balanced regulation. The rating agencies also play a crucial role in how our industry is viewed and how we gain credibility in the marketplace. At GE Insurance Solutions, it is our intention to be a leader in striving for open and fair dealings between insurers, brokers and clients. We recently published our market transparency principles, which are designed to ensure full transparency of broker compensation for services rendered to clients on business involving GE Insurance Solutions and its subsidiaries.

Our marketing transparency principles centre on transparency, disclosure and consent, so that all parties have full disclosure of all payments. We are also determined to clarify all terms that are used in contract wordings. We are encouraged by the initial response to our new guidelines and we are beginning to work with brokers and agents to put these guidelines into action.

Our marketing transparency principles are just the first visible action from our initiative called Challenge All Industry Norms (CAIN). We are looking at industry practices with a fresh perspective. We intend to address issues that could create conflicts of interest or other risks to our integrity and take appropriate steps to resolve them. The objective is to challenge ourselves to meet the highest standards of business behaviour globally.

\section{The heart of our business: underwriting}

We are also determined to lead the industry in the right direction when it comes to underwriting performance. In 2004, the U.S. property and casualty (P\&C) industry saw its first underwriting profit in 25 years. It is expected - barring unforeseen major losses - that the industry will post an underwriting profit in 2005 as well (see Figure 1). Still, our industry has not been consistent in its underwriting discipline, and that has driven the poor performance of the past decades. There is only one solution for this: We must put an end to our pricing cyclicality through underwriting discipline and accurate pricing. There are emerging risks we must start pricing for now, especially in the face of this soft cycle: carbonless paper, blogging, silicosis, obesity, and others. But how can we be certain we are pricing accurately? How can we underwrite the volatility of these emerging issues? I think there are a few lessons learned from asbestos that can help us with these new threats. Underwriting is at the 


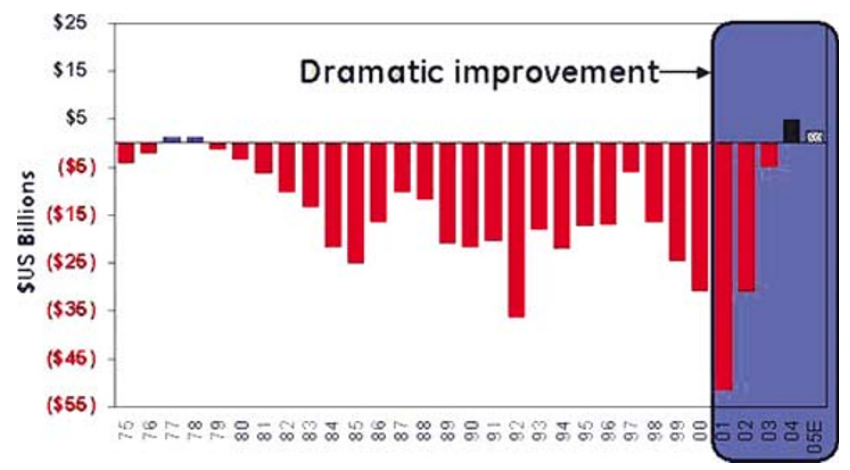

Figure 1. Promising progress on underwriting. Source: A.M. Best, Insurance Information Institute. Reprinted with permission from Insurance Information Institute.

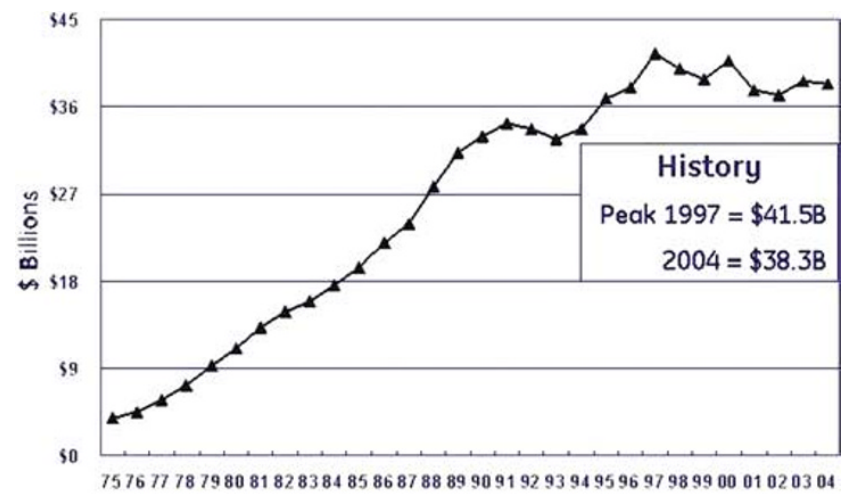

Figure 2. Investment performance remains solid. Source: A.M. Best, ISO, Insurance Information Institute. Reprinted with permission from Insurance Information Institute.

heart of our challenge; so how does an industry that does not make a profit selling its core product survive?

The obvious answer has been investments (see Figure 2). As an industry, we have overcome our underwriting shortcomings with solid - and sometimes spectacular - investment performance. However, as we all know, the growth in investment returns has peaked with no immediate signs of a surge in performance. So, the P\&C industry must make money the old-fashioned way - through underwriting.

On the other hand, one of the reasons our industry is viewed poorly by some investors is because of our operating returns. Using U.S. P\&C insurers as a proxy for the industry, Figure 3 shows our return on equity has not kept pace with our cousins in diversified financial services. 


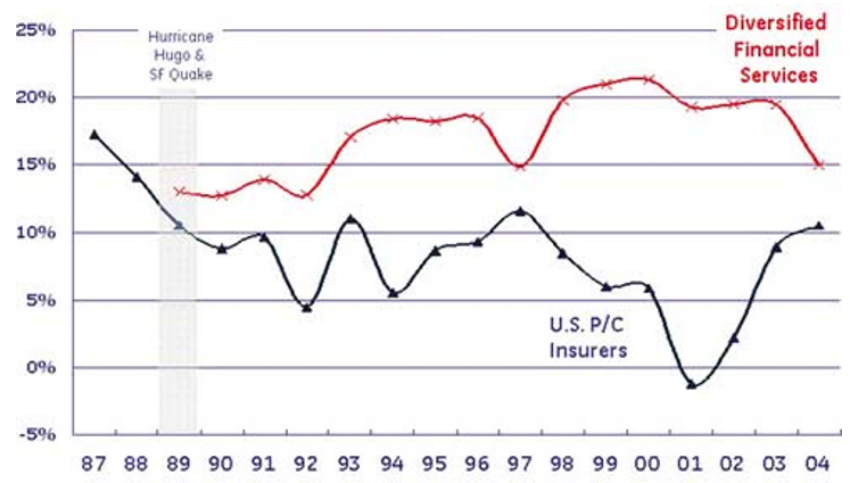

Figure 3. Investor returns insufficient. ROE: Financial services industry segments, 1987-2004. All figures GAAP except $2004 \mathrm{P} / \mathrm{C}$ figure is return on overage surplus. Source: Insurance Information Institute, Fortune Volume Line. Reprinted with permission from Insurance Information Institute.

The tough reality is that we have delivered a great deal of volatility in $\mathrm{P} \& \mathrm{C}$ insurance, but we have failed to generate returns that compensate investors for that volatility (at least not since 1987). We must work to correct this.

\section{Loss costs}

Loss-cost growth poses an ongoing threat to our $\mathrm{P} \& \mathrm{C}$ marketplace. As indicated in Figure 4, the U.S. industry's loss-cost rose at a faster pace than underlying premium growth for more than a decade, finally resulting in equilibrium in 2005 .

However, during the past 17 years, we have moved from an industry generating 17 per cent returns to an industry generating 11 per cent returns. We have lost 400 basis points in investment yield and we are no longer writing at a 2:1 premium to surplus ratio. That puts increasing pressure on us to focus on loss costs and ensure that our pricing is accurately reflecting the changes in the loss environment over time.

We believe consistent pricing and steady improvements are needed to keep up with the growth in loss costs if we are to improve industry return on equity. We must also determine what our investors' expectations are for long-term returns. One way to improve our performance is to procure more accurate data about underlying risks. The demographics of our world are changing, and unless we are aware of those changes and improve our pricing, we will continue to have unanticipated losses.

We know loss-cost inflation is eating away at the fundamental fabric of our longterm financial performance as an industry. So, what can we do about it? A review of the facts is in order. 


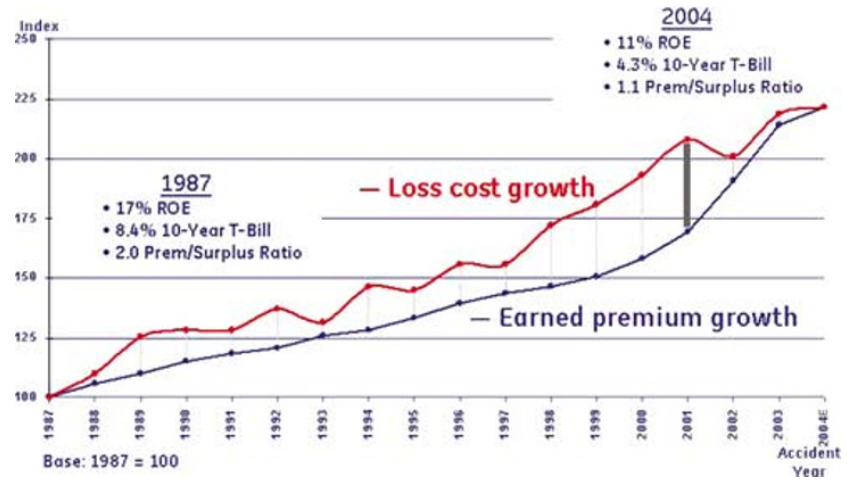

Figure 4. Dramatic shift in industry dynamics. Source: Internal GE Insurance Solutions Research, A.M. Best Aggregates \& Averages, ISO.

\section{Catastrophes}

Our world has become more complex, more unpredictable and riskier. Katrina was a wake-up call, and we must respond. Today's cat models are good, but insufficient to capture all the variables that we now must recognize. Upwards of $\$ 50$ billion in capital has been destroyed by the 2005 storms, and the rating agencies have become more demanding. We have to be compensated for the increased exposures we are assuming.

Perhaps more challenging is the realization that seven of the top 10 disasters of all time have happened in the past 4 years. None of us can afford to bet our companies that these trends will suddenly improve next year.

We must recognize that hurricane-exposed areas of North America are facing a volatile phase in weather cycles. It is well known that hurricanes occur in cyclical patterns. Since the 1970s, we have been in a relatively benign cycle, until the past 5 years. And if those past 5 years are any indication, the first decade of this century is likely to look a lot like the 1940 s - the most violent hurricane cycle in the past 100 years.

Another concern is the "clustering effect" of storm risks. Clustering is the impact of having hurricanes or storms that cluster and make landfall. In 2004, we had a cluster of four hurricanes that came in one after the other. This happened because the storms grouped in the ocean and pushed each other onto the mainland. The probability of clustering increases the probability of landfall. So how can underwriters predict the probability of clustering? Currently, there are no reliable models for predicting this risk. All these challenges point back to one obstacle - the process will work when the data are robust.

From a long-term perspective, we cannot ignore global warming. Everyone agrees climate change is a factor in underwriting. The Earth is clearly getting warmer, but what are the implications for us? It may mean that we need to revisit our assumptions about exposures, pricing and volatility. Currently, under- 
writers are using models that are not programmed to take this factor into consideration.

\section{Terrorism}

The issue of terrorism must also remain at the forefront of our thinking. Terrorist attacks are premeditated. There is no way for experts or actuaries to build models to predict these attacks. Clearly these attacks are costly in human terms and in economic disruption.

While we are getting better at estimating the impact of a variety of terrorist attacks, no insurer can predict frequency or probability.

The U.S. faces some critical decisions about the renewal of TRIA, the governmentsupported terrorism backstop. Our view is that it should be renewed, with the ultimate goal of establishing a programme similar to the Pool Re concept used in the United Kingdom. At the time of the writing of this paper, the current revision of TRIA includes unrealistic caps that will overextend the industry financially. Also, there are a lot of changes that need to take place in regard to insurance regulations. For example, there are some states that do not allow insurers to exclude terrorism coverage. In the states that do allow exclusion of terrorism, they do not allow exclusion of fire following. These contradicting rules must be addressed before the industry has the right environment in which it can develop a long-term terrorism insurance solution.

At the Geneva Association General Assembly in June 2005, we discussed whether this is an industry or a set of businesses pursuing similar goals. I think there is too much at stake when we discuss terrorism and some other industry issues for us to be anything less than a cohesive industry at work. We must fulfill our mission as a foundation of the global economy. This is clearly an issue upon which we, as an industry, have to speak directly and with one voice to find a balanced solution for society.

\section{Torts}

Last, but not least, the rapid increase in tort costs continues to plague our industry and the economy in general. We must focus on bringing balance and logic to the U.S. tort system. At the same time, we must provide fair, even generous, civil awards for people injured by others' errors. Who would have thought that we could generate USD 300 billion annually in tort costs in the United States? ${ }^{1}$

\footnotetext{
${ }^{1}$ Towers Perrin data presented to internal GE Insurance Solutions audience. Permission to use data granted by Towers Perrin.
} 
The United States is not alone in facing these tort costs. The "litigation virus" has infected Europe and Asia. It would be naïve to think the rest of the world is insulated and exempt from these increasing cost trends.

\section{Delivering what customers want}

So what do we need to do as an industry to improve our standing? In addition to facing and eliminating the issues discussed, we must deliver what customers want:

- Consistency - not cyclicality;

- Service - expertise to help manage risk;

- Security and financial strength - restoring ratings to ensure long-term credibility;

- Integrity - we must earn the trust of our customers.

Our investors and rating agencies want the same focus on consistency along with a double digit operating return. So how do we deliver? We focus on customer service. It's at the centre of GE Insurance Solutions' brand promise. Six Sigma rigour drives our business. In the traditional services area, we use Six Sigma to improve processes that are designed to make it easier for our customers to do business with us. Our "At the Customer, For the Customer" expert services and advanced risk analytics are some key areas where GE Insurance Solutions provides services to help make our customers' businesses better.

\section{Outlook}

While we face daunting challenges and issues, our industry has the ability to overcome them. We are seeing progress in underwriting performance, changes in laws that may stem the rise of tort costs, in improved catastrophe modelling. These changes in our practices - from underwriting discipline to tort reform - reinforce an optimistic outlook.

In the end, our industry continues to play a critical role in the global economy. We have a noble cause and a promise built on a foundation of financial strength supported by integrity and transparency; we must honour the trust placed in us.

All our stakeholders expect greater consistency and higher performance from us, and we can deliver on these goals. We must seize opportunities ahead to work together globally where we can to drive change in our industry that delivers consistency for our clients, our investors, our regulators and our employees.

\section{About the Author}

Ron Pressman is President and CEO of GE Insurance, and Chairman, President and CEO of GE Insurance Solutions, one of the world's largest reinsurance and insurance organizations. In addition, Mr. Pressman serves as a member of the GE Corporate Executive Council reporting to GE CEO Jeff Immelt and as a director of GE Capital 
Services. He was elected an officer of the General Electric Company in 1993 and Senior Vice President in July 2000. Mr. Pressman has held an array of roles in GE, leading GE Capital Real Estate as President and CEO from 1997 to 2000. Prior to that, he was CEO of GE Power Systems Europe and led several business units for GE Power Systems. In 1990's he assumed his first business leadership position as General Manager of GE's Central and Eastern Europe operations based in London. Mr. Pressman began his career with GE in 1980. Mr. Pressman graduated from Hamilton College in Clinton, New York, in 1980. 